\title{
Genetics and genomics in IBS: A primer for the neurogastroenterologist
}

\section{Genética y genómica en el SIl: Una introducción para el neurogastroenterólogo}

\author{
Francisco Lozano-Hernández ${ }^{1}$ and Ruth Gutiérrez-Aguilar ${ }^{2,3 *}$ \\ ${ }^{1}$ Gastroenterología y Nutrición Pediátrica, Centro Médico Naval de la Secretaría de Marina; ${ }^{2}$ División de Investigación, Facultad de Medicina, Universidad \\ Nacional Autónoma de México (UNAM); "Laboratorio de Enfermedades Metabólicas: Obesidad y Diabetes, Hospital Infantil de México "Federico Gómez"
} (HIMFG), Mexico City, Mexico

\begin{abstract}
Irritable bowel syndrome (IBS) is a gut-brain interaction disorder characterized by recurrent or chronic abdominal pain associated with an alteration in the normal pattern of stool consistency. In more than $20 \%$ of patients with IBS, there is comorbidity with depression and anxiety impacting on quality of life. The pathophysiology of IBS is not fully understood, but it involves the neural, endocrine, and immune systems as dysfunctional signaling processes of the gut-brain axis and genetic factors. The goal of this review is to prime neurogastroenterologist into genetic or genomic studies. We will describe the different strategies used to discover the genes involved in the development of IBS. We will briefly explain general considerations for genetic studies, the different cohorts used for genetic studies (familial, case-control, general population), and approaches used for these studies (candidate genes or genome wide- association studies). Moreover, we will describe some of the genes associated with IBS. Genetic and genomic studies have been crucial to identify several gene variants associated with IBS.
\end{abstract}

Keywords: Irritable bowel syndrome. Genetics. Genomics. Candidate genes. Genome-wide association studies.

\section{RESUMEN}

El síndrome de intestino irritable (SII) es un trastorno de la interacción intestino-cerebro, que se caracteriza por el dolor abdominal recurrente o crónico y está asociado a la alteración en el patrón normal de la consistencia de las heces. En más del 20\% de los pacientes con SII existe comorbilidad con depresión y ansiedad, lo que repercute de forma importante en la calidad de vida. La fisiopatología del SII no se comprende completamente, pero involucra al sistema neural, endocrino e inmunológico en procesos de señalización disfuncional del eje intestino-cerebro y factores genéticos. El objetivo de esta revisión es acercar a los neurogastroenterólogos a los estudios genéticos y genómicos. Se describirán diferentes estrategias utilizadas en el descubrimiento de genes involucrados en el desarrollo del SII. También, se explicarán brevemente las consideraciones generales para los estudios genéticos, las diferentes cohortes que se utilizan (familiar, caso-control y población general), así como los abordajes manejados para estos estudios (genes candidato o estudios de asociación al genoma completo). Además, se describirán algunos

Correspondence to:

*Ruth Gutiérrez-Aguilar

E-mail: ruthgutz@unam.mx
NeuroGastroLatam Rev. 2021;5:170-187

Received in original form: 03-07-2021

Accepted in final form: 03-11-2021

DOI: 10.24875/NGL.21000012

2462-7011/@ 2021 Sociedad Latinoamericana de Neurogastroenterología, A.C. Published by Permanyer. This is an open access article under the CC BY-NC-ND license (http://creativecommons.org/licenses/by-nc-nd/4.0/). 
de los genes candidatos asociados a SII, así como variantes descubiertas por un abordaje sin hipótesis, los estudios de asociación al genoma completo. Los estudios genéticos y genómicos han sido cruciales para identificar diversas variantes génicas asociadas al SII.

Palabras clave: Síndrome de intestino irritable. Genética, genómica. Genes candidatos. Estudios de asociación del genoma completo.

\section{INTRODUCTION}

Irritable bowel syndrome (IBS) is a gut-brain interaction disorder (GBID), formerly considered a functional gastrointestinal disorder $(\text { FGID })^{1}$. GBIDs are defined as a group of disorders classified by gastrointestinal (GI) symptoms related to any combination of: motility disturbance, visceral hypersensitivity, altered mucosal and immune function, altered gut microbiota and altered central nervous system (CNS) processing ${ }^{2}$. The Rome IV criteria define IBS as recurrent abdominal pain for at least 1 day per week in the past 3 months, associated with 2 or more of the following criteria: abdominal pain related to defecation, a change in stool frequency and/or in stool form ${ }^{3}$. These defecation problems are typically present in three types: constipation, diarrhea, or a mix of constipation and diarrhea, presenting symptoms of abdominal bloating and/or distention. Therefore, IBS is classified into four subtypes: IBS with diarrhea (IBS-D), IBS with constipation (IBS-C), IBS with mixed symptoms of constipation and diarrhea (IBS-M), or unsubtyped IBS (IBS-U) ${ }^{4}$.

A systematic review reported a prevalence that varies between countries, from $1.1 \%$ in France and Iran to $35.5 \%$ in Mexico. The average regional prevalence was reported on $17.5 \%$ in Latin America, $9.6 \%$ in Asia, $7.1 \%$ in North America/Europe/Australia/New Zealand, and 5.8\% in the Middle East and Africa ${ }^{5}$.
Recently, in 2021, a study described the prevalence, the global distribution, and associated factors of FGIDs in 33 countries. Of the 73,076 adults surveyed, $49.5 \%$ were women. Most of the countries revealed a prevalence of IBS between 3 and 5\%, affecting 1.8 times more women than in men ${ }^{6}$.

IBS is often associated with psychiatric comorbidities. A recent meta-analysis showed a prevalence of more than $20 \%$ of both depression and anxiety, in people with IBS ${ }^{7}$.

Although it is true that IBS does not modify mortality rates, it does have a significant impact on the quality of life of patients. In addition, IBS has a general economic repercussion, since it generates high costs for the patient and the health systems during the diagnosis and treatment process. Moreover, it also causes absenteeism from work in adults and loss of productivity in parents; in children IBS causes absenteeism from school ${ }^{8}$. Therefore, there is a clear need to better understand this disease from the clinical and molecular domains to help the patient cope with it.

IBS pathophysiology is incompletely understood. However, it is hypothesized that the symptoms originate from dysfunctional signaling of the brain-gut axis, including three main systems: neural, endocrine, and immune. 
IBS is considered a multifactorial disease, where environmental and genetic factors can influence the development of the disease. Some of the environmental factors are diet, stress, microbiome, which in turn conditions anxiety and depression ${ }^{7}$. On the other hand, genetics and genomics have been crucial to identify several genes associated with IBS. Accordingly, in the current review, we describe the basis of genetic and genomic studies of IBS, as well as some of the gene variants that have been associated with this GBID.

\section{METHODOLOGY}

Relevant papers about genetics and/or genomics of IBS published from 2005 to 2021 were searched using platforms such as PubMed, Cochrane Reviews, SciELO and ScienceDirect. The words used for this search were IBS, genes, genetics, genomics, genome wide association studies, meta-analysis, ethnicities, and pathophysiology.

\section{RESULTS}

IBS is a multifactorial disease, where environmental and genetic factors play an important role in the development of this disease.

Several risk factors have been associated with IBS pathogenesis, including: visceral hypersensitivity, dysbiosis of the intestinal microbiota, immune activation, GI infections, dietary factors, perinatal factors, psychological stressors, depression, and traumatic experiences such as child abuse, punishment, or parental rejection ${ }^{9}$. Then, IBS is a multifactorial disease where the environment plays an important role in this disease. However, in this review, we will only focus in the genetic factors that give susceptibility to develop IBS.

\section{Genetic factors leading to IBS}

In this section, we want to introduce our readers to the tactics used to perform genetic or genomic studies. We will describe the different strategies used to discover the genes involved in the development of IBS. We will briefly explain general considerations for genetic studies, the different cohorts used for genetic studies (familial, case-control, and general population), and approaches used for these studies (candidate genes or genome wide- association studies [GWAS]).

\section{Genetic considerations for genetic studies}

Monogenic diseases are caused by rare mutations (present in less than 1\% of the population) of a single gene and their effect provokes a malfunction of the gene, leading to the development of the disease. On the other hand, several genes cause polygenic diseases, such as IBS. In the polygenic diseases, the gene variants are commonly present among the individuals (more than $1-5 \%$ of the population) and the addition of the effect of multiple variants (from different genes) confer the susceptibility to develop a disease.

In this section, we will describe the steps followed to perform a genetic study of a polygenetic disease, such as IBS. 


\section{Discovery}

In genetic studies, the first step is the discovery of genetic variants associated with a disease. This is normally performed with a case-control cohort, where several polymorphisms could be genotyped and analyzed to be associated with the disease ${ }^{10}$.

\section{Replication}

Once we have discovered a variant associated with the disease, the second step is the replication in several populations. The replication in different populations indicates that a gene is a plausible physiological actor on the disease ${ }^{10}$. One limitation to find association between the gene variant(s) and the disease is the small sample used in the cohorts. This leads to lack of statistical power (lower than $80 \%$ ), given by the minor allele frequency, the odd ratio (OR) or risk, and the sample size. In polygenic diseases, the variant's OR is usually low, and the allele frequency is common (30-50\%), so it all depends on the sample size to be able to achieve a statistical power over $80 \%$ and analyze the association between the gene variants and the disease. Therefore, replication and the sample size are important factors to take into consideration when performing genetic studies ${ }^{11}$.

\section{Ethnicity and meta-analysis}

Ethnicity is another factor to consider while analyzing genetic data. It is possible that a gene variant could be associated with IBS in a Caucasian population, but not in an
Asiatic one, or vice versa. To cope with this problem, meta-analysis studies are performed $^{12}$.

A meta-analysis study is part of a systematic review. The meta-analysis consists of gathering all the existing data of previous studies, where association of genetic variants with a disease was reported in different populations. Then, statistical tests have to be performed, considering all those previous studies and calculate a new OR for the variant. Therefore, having the overall analysis, we can conclude if a gene variant is associated with a specific disease, considering the ethnicity ${ }^{13,14}$.

\section{Cohorts used for genetic studies}

\section{FAMILIAL STUDIES}

Twin and familial studies were the main strategies used to understand the genetic implication behind any disease. Monozygotic twins share $100 \%$ of their genome and dizygotic twins only share $50 \%$.

A study involving 281 American twin pairs showed that monozygotic twins have $17 \%$ concordance for IBS, while $8 \%$ for dizygotic twins ${ }^{15}$. Another study with 3334 Norwegian twin pairs also showed a higher concordance rate for IBS (22\% monozygotic vs. $9 \%$ dizygotic) (Fig. 1A). Moreover, the IBS heritability was $48 \%{ }^{16}$, showing that genetics is a key factor in the development of IBS.

Another strategy to study the impact of genes on a disease is the adoption studies. Then, we can analyze the influence of the genetic background versus the environment where they 
are raised. Interestingly, adoptees whose biological parents suffer IBS present an OR or risk for IBS of 1.67 (95\% CI: 1.06-2.62). Whereas, for adoptees whose adoptive parents present IBS was 0.88 (95\% CI: 0.48-1.63) ${ }^{17}$ (Fig. 1A). Therefore, twin and the adoptive studies add another proof that genetics play an important role in the development of IBS over the environment.

\section{CASE-CONTRol studies}

IBS has been described to be a polygenic disease, meaning that several genes are involved in the development of the disease. The discovery of the single nucleotide polymorphism or variants (SNVs), by the human genome sequence, opened a new way of studying genetics. SNVs are a variation of a single base pair or nucleotide in the genome, representing $1 \%$ of our genome and conferring the difference among individuals. A SNV (catalogued as rs\#) is a common change in the genome (more than $5 \%$ of the population has a SNV) and confers susceptibility to develop the disease. However, a mutation is a rare change of a nucleotide in the genome, its frequency is low (less $1 \%$ of the population has the variant), and generally leads to the development of a disease.

The SNVs are used to do association studies that consist on comparing the allele frequency of the variant between case and control subjects. These studies are called case-control studies, based on cohorts of people presenting the disease (case) and without the disease (controls) (Fig. 1B). To do this comparison, we can use a Chi-sqaure to obtain the OR. OR values above 1 represent a risk to develop the disease; and OR values below 1 represent a protection to get the disease $\mathrm{e}^{18}$.

Several genes have been discovered using this approach. For example, the serotonin re-uptake transporter (SERT or SLC6A4 deletion/deletion) was associated with IBS using a case-control cohort of 150 IBS patients and 252 controls, reporting an OR of 2.6 (1.4-4.9) and $\mathrm{a} \mathrm{p}=0.003^{19}$. Another example is the association of the serotonin receptor type 3 (HTR3E 3'UTR variant c. *76G_A, rs62625044) with IBS-D by analyzing 100 patients and 100 healthy controls of an English population, showing an OR of 8.53 (1.04-70.28), p = 0.033. In addition, in this same study, they analyzed a German population, where they were able to replicate the association with IBS shown before $(\mathrm{OR} \text { of } 4.92 \text { and } \mathrm{p}=0.0046)^{20}$.

\section{General population}

General population studies are based on recruiting people without knowing the state of the disease, meaning that a subject could have the disease or not, or he/she could be on the stage of developing it. These types of studies are very useful to identify intermediate phenotypes and genes that could be important for the development of the disease (Fig. 1C). Prospective studies based on the general population are used to obtain biomarkers that could predict the progress of a disease in the future ${ }^{10}$.

For example, COMT Val158Met polymorphism was evaluated in 867 subjects representative of a general population. Val/Val COMT variant was associated with IBS (OR 3.98, $\mathrm{p}=0.046)$ and carriers of this polymorphism 
presented increased bowel frequency (stools per day; OR 5.3, $\mathrm{p}=0.03)^{21}$.

An interesting example summarizing all what has been explained up to this point is a paper published by Ek et al., where they analyzed a general population sample of 11,326 Swedish twins, selecting 534 cases and 4932 controls for the discovery study. Over one million SNVs were analyzed, finding 42 independent genomic regions with suggestive association. Secondly, they performed a replication study using 6 different population case-control cohorts. Then, they completed a meta-analysis of all those cohorts of different populations and reported that rs 12702514 (T/C) have an OR of 1.21 (1.13-1.30) with a $\mathrm{p}$-value of meta-analysis of $5.46 \times 10^{-06}$. This variant is close to the gene KDELR2 that will be further discussed in GWAS section ${ }^{10}$.

Therefore, different types of cohorts (familial, case-control or general population) are used to identify gene variants associated with a disease, such as IBS. After selecting the type of genetic study and the cohort, the next step is to decide the approach to analyze the genes: (1) candidate genes or (2) GWAS, the most commonly used in the last decades.

\section{Approaches used for genetic studies}

\section{Candidate genes "from physiology to GENETICS"}

As mentioned above, IBS has a genetic component already established by familial studies. The next step is to identify the exact genes that could be provoking the disease or that confer susceptibility to develop it.
A candidate gene approach consists of knowing the cellular or physiological function of a gene, and then, look for its association with a disease in a cohort. Reason why we commonly say that we go "from physiology to genetics" (Fig. 1D). However, the main limitation of a candidate gene approach is that the function of the gene has to be known beforehand. In addition to this limitation, we can just study a few genes at the same time, by a trial and error approach.

Several reviews about IBS genetics or genomics have been published in the last decade, describing more than 65 polymorphisms of different genes associated with IBS. Some of the functions of these candidate genes are related to serotonergic, adrenergic, or opioidergic systems, as well as neuromodulatory, immune activation and inflammation, intestinal secretion and motility, among others ${ }^{22-24}$. In addition, meta-analysis studying the immunogenetics of IBS $^{25}$ or the serotonin receptor's association with IBS has been reported $^{13}$. A recent systematic review and meta-analysis described the candidate genes associated with IBS. In this study, 66 variants were selected to be considered for the meta-analysis, from 3810 publications of IBS related polymorphisms published between 2000 and 2018. After applying their inclusion criteria, only 10 polymorphisms, from 28 studies, were evaluated for their association with $\mathrm{IBS}^{14}$.

In the next section, we will briefly describe some of the candidate genes implicated in the pathophysiologic mechanisms involved in IBS: neural, endocrine and immune pathways. In Table 1, genes that are associated and have been confirmed by meta-analysis are 
1) Cohorts used for genetic studies

A. Familial studies

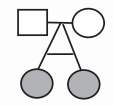

Monozygotic twinsDizygotic twins

$22 \%$ IBS

concordance $^{16} \quad$ concordance $^{16}$

Adoption studies

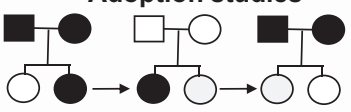

OR $1.67^{17}$ OR $0.88^{17}$

D. Candidate genes

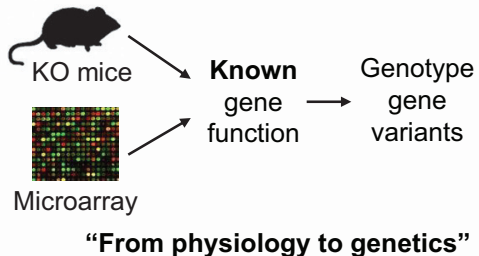

"From physiology to genetics"
B. Case-control studies
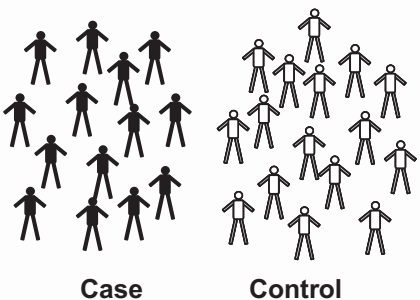

C. General population

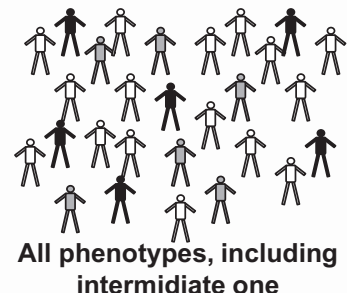

\section{2) Approaches used for genetic studies}

\section{E. Genome wide-association studies (GWAS)}

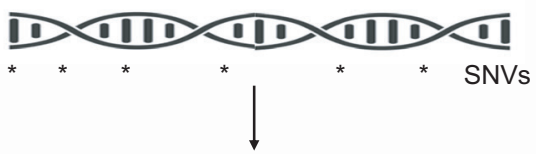

Allele frecuency case-control

"From genomics to physiology"

Figure 1. Different cohorts and approaches used in genetic studies. 1) Cohorts used for genetic studies. A: familial: twin or adoption cohorts. B: case-control cohorts. C: general population cohort. 2) Approaches used for genetic studies. D: candidate genes. E: genomewide association studies (genome wide- association studies).

indicated; the other genes have been associated in a few studies, but the replication has to be confirmed in more populations (Table 1).

\section{Neural pathway}

CNS can modulate visceral afferent signals, resulting in the facilitation or inhibition of endogenous pain. Functions of the GI tract are modulated by intrinsic and extrinsic innervation, mediated by the autonomic nervous system: parasympathetic and sympathetic. The parasympathetic nervous system stimulates smooth muscle and secretory actions, while the sympathetic inhibits the motor and secretory activity of the
GI tract ${ }^{26}$. The intrinsic or enteric nervous system provides local reflexes, such as migrating motor complex and peristaltic reflexes, and yet also receives input from the CNS through the autonomic nervous system ${ }^{27}$.

The dysfunctional gut-brain axis is observed in the pathogenesis of IBS. The existence of autonomic dysfunction in IBS has been hypothesized. Low vagal activity can lead to a reduction in bowel contractions, reduced motility, and constipation, while high vagal activity can result in increased contractions and diarrhea ${ }^{28}$.

A subset of IBS patients develop symptoms after an acute GI infection, as a transient process that returns to normal after resolution of 
TABLE 1. Genes associated with IBS discovered by gene candidate approach and some are confirmed by meta-analysis

\begin{tabular}{|c|c|c|c|c|c|}
\hline Closest gene & Gene function & Variants & $\begin{array}{l}\text { Possible } \\
\text { associated } \\
\text { effect }\end{array}$ & Type of IBS & Reference \\
\hline \multicolumn{6}{|c|}{ Neural pathway } \\
\hline $\begin{array}{l}\text { SLC6A4 (Solute Carrier } \\
\text { Family } 6 \text { Member 4) }\end{array}$ & $\begin{array}{l}\text { Encodes for SERT, transporter in } \\
\text { serotonin reuptake }\end{array}$ & $\begin{array}{l}\text { 5-HTTLPR (Short } \\
\text { variation) }\end{array}$ & $\begin{array}{l}\text { Decreases the } \\
\text { activity of SERT } \\
\text { and accelerates } \\
\text { intestinal } \\
\text { peristalsis }\end{array}$ & $\begin{array}{l}\text { IBS-D (in } \\
\text { Mongoloid } \\
\text { ethnicity) }\end{array}$ & $\begin{array}{l}\text { Meta-analysis } \\
14,31,32\end{array}$ \\
\hline $\begin{array}{l}\text { COMT (Catechol 0-Methyl- } \\
\text { transferase) }\end{array}$ & Degradation of catecholamines & $\begin{array}{l}\text { rs4680 (G/A) } \\
\text { (Val158Met) }\end{array}$ & $\begin{array}{l}\text { Decreases its } \\
\text { enzyme activity } \\
\text { and pain threshold }\end{array}$ & IBS & $\begin{array}{l}\text { Meta-analysis } \\
14,21\end{array}$ \\
\hline $\begin{array}{l}\text { NPSR1 } \\
\text { (Neuropeptide S Receptor) }\end{array}$ & $\begin{array}{l}\text { Involved in stress, fear and } \\
\text { anxiety. Increases the expression } \\
\text { of CCK, somatostatin and } \\
\text { peptide } Y \text {. }\end{array}$ & rs1379928 A/G & $\begin{array}{l}\text { Increased } \\
\text { intestinal motility, } \\
\text { gas, abdominal } \\
\text { pain and urgency } \\
\text { to defecate }\end{array}$ & IBS-D & $\begin{array}{l}\text { Neural and } \\
\text { endocrine pathway } \\
33\end{array}$ \\
\hline \multicolumn{6}{|c|}{ Endocrine pathway } \\
\hline $\begin{array}{l}\text { CRF1 and CRF2 (CRHR1 and } \\
\text { CRHR2) (Corticotropin } \\
\text { Releasing Hormone } \\
\text { Receptor } 1 \text { and 2) }\end{array}$ & $\begin{array}{l}\text { Modulates the HPA axis and } \\
\text { inflammation of the intestinal } \\
\text { mucosa. }\end{array}$ & $\begin{array}{l}\text { TT rs7209436 } \\
\text { rs } 4722999 \mathrm{C} / \mathrm{T} \\
\text { rs3779250 C/G }\end{array}$ & $\begin{array}{l}\text { Increased in } \\
\text { stress and anxiety }\end{array}$ & IBS & $\begin{array}{l}\text { Meta-analysis } \\
14,37,63\end{array}$ \\
\hline $\begin{array}{l}\text { CNR1 (Cannabinoid } \\
\text { Receptor 1) }\end{array}$ & $\begin{array}{l}\text { Mediates many cannabinoid-in- } \\
\text { duced effects, including GI } \\
\text { motility, anxiety, chronic pain }\end{array}$ & $\begin{array}{l}\text { AAT triplet in } 3^{\prime} \\
\text { flanking region } \\
\text { rs } 806378 \mathrm{C} / \mathrm{T}\end{array}$ & $\begin{array}{l}\text { Severity of } \\
\text { abdominal pain } \\
\text { Increases colonic } \\
\text { transit }\end{array}$ & IBS-D & 38 \\
\hline $\begin{array}{l}\text { FAAH (Fatty Acid Amide } \\
\text { Hydrolase) }\end{array}$ & $\begin{array}{l}\text { Inactivates anandamide, the main } \\
\text { endocannabinoid }\end{array}$ & FAAH C385A & $\begin{array}{l}\text { It is inactivated } \\
\text { and releases } \\
\text { acetylcholine; } \\
\text { rapid colon } \\
\text { transit. }\end{array}$ & IBS-D & 38 \\
\hline $\begin{array}{l}\text { CCK1-R (Cholecystokinin-1 } \\
\text { Receptor) }\end{array}$ & $\begin{array}{l}\text { Modulates colon motility and } \\
\text { gastric emptying }\end{array}$ & intron $1,779 \mathrm{~T} / \mathrm{C}$ & $\begin{array}{l}\text { Delay in gastric } \\
\text { emptying }\end{array}$ & $\begin{array}{l}\text { IBS-C and } \\
\text { IBS-M }\end{array}$ & 40 \\
\hline \multicolumn{6}{|c|}{ Immune pathway } \\
\hline IL6 (Interleukin 6) & $\begin{array}{l}\text { Powerful inducer of the acute } \\
\text { inflammatory response }\end{array}$ & rs $1800795 \mathrm{C} / \mathrm{G}$ & $\begin{array}{l}\text { Probably } \\
\text { inflammation of } \\
\text { the bowel mucosa }\end{array}$ & $\begin{array}{l}\text { IBS-U (in } \\
\text { Caucasians } \\
\text { subgroup) }\end{array}$ & $\begin{array}{l}\text { Meta-analysis } \\
14\end{array}$ \\
\hline $\begin{array}{l}\text { IL23R (Interleukin } 23 \\
\text { Receptor) }\end{array}$ & $\begin{array}{l}\text { Binds IL23 and mediates T-cells, } \\
\text { NK cells and macrophages }\end{array}$ & rs11465804 T/A & $\begin{array}{l}\text { Probably } \\
\text { inflammation of } \\
\text { the bowel mucosa }\end{array}$ & IBS-C & $\begin{array}{l}\text { Meta-analysis } \\
14\end{array}$ \\
\hline IL10 (Interleukin 10) & $\begin{array}{l}\text { Limits and may ultimately cease } \\
\text { inflammatory responses }\end{array}$ & rs1800896 T/C & $\begin{array}{l}\text { Anti-inflammatory } \\
\text { protector }\end{array}$ & $\begin{array}{l}\text { Lower risk of } \\
\text { IBS }\end{array}$ & $\begin{array}{l}\text { Meta-analysis } \\
14,48\end{array}$ \\
\hline IL8 (Interleukin 8) & $\begin{array}{l}\text { Involved in the initiation and } \\
\text { amplification of acute inflamma- } \\
\text { tory responses and in chronic } \\
\text { inflammation }\end{array}$ & IL8 + $396 \mathrm{G} / \mathrm{G}$ & $\begin{array}{l}\text { Transient mucosal } \\
\text { inflammation }\end{array}$ & $\begin{array}{l}\text { IBS (in } \\
\text { Mexicans) }\end{array}$ & 49 \\
\hline
\end{tabular}


TABLE 1. Genes associated with IBS discovered by gene candidate approach and some are confirmed by meta-analysis (Continued)

\begin{tabular}{|c|c|c|c|c|c|}
\hline Closest gene & Gene function & Variants & $\begin{array}{l}\text { Possible } \\
\text { associated } \\
\text { effect }\end{array}$ & Type of IBS & Reference \\
\hline $\begin{array}{l}\text { TNFSF15 (TL1A) (TNF Super- } \\
\text { family Member 15) }\end{array}$ & $\begin{array}{l}\text { Encodes for TL1A, which is a } \\
\text { member of the tumor necrosis } \\
\text { factor superfamily. It binds to } \\
\text { death receptor } 3 \text { (DR3), triggering } \\
\text { secretion of interleukin } 17\end{array}$ & $\begin{array}{l}\text { rs4263839 A/G } \\
\text { rs6478108 C/T }\end{array}$ & $\begin{array}{l}\text { Probably } \\
\text { inflammation of } \\
\text { the bowel mucosa }\end{array}$ & $\begin{array}{l}\text { IBS-C } \\
\text { IBS }\end{array}$ & $\begin{array}{l}\text { Meta-analysis } \\
14,25\end{array}$ \\
\hline \multicolumn{6}{|c|}{ Other mechanisms } \\
\hline $\begin{array}{l}\text { SCN5A (Sodium Volt- } \\
\text { age-Gated Channel Alpha } \\
\text { Subunit 5) }\end{array}$ & $\begin{array}{l}\text { Expressed in the intestinal } \\
\text { smooth muscle cells and } \\
\text { interstitial cells of Cajal that } \\
\text { mediate the Gl contractions }\end{array}$ & p. A997T-NaV1.5 & $\begin{array}{l}\text { Reduction of the } \\
\mathrm{Na}^{+} \text {current } \\
\text { impairing its } \\
\text { function and } \\
\text { leading to a } \\
\text { channelopathy }\end{array}$ & $\begin{array}{l}\text { IBS-C and } \\
\text { IBS-D } 2 \% \\
\text { IBS patients } \\
\text { carry } \\
\text { mutations in } \\
\text { SCN5A. }\end{array}$ & 11,57 \\
\hline SI (Sucrase-Isomaltase) & $\begin{array}{l}\text { Disaccharidase enzyme present } \\
\text { in the small intestine, degradates } \\
\text { starch or digested sugars }\end{array}$ & Variant Val15Phe & $\begin{array}{l}\text { Carbohydrates } \\
\text { malabsorption. } \\
\text { This variant } \\
\text { reduced } 35 \% \text { the } \\
\text { enzyme activity. } \\
\text { Correlated with } \\
\text { increased stool } \\
\text { frequency and } \\
\text { abundance of } \\
\text { parabacterium } \\
\text { fecal microbiota }\end{array}$ & IBS-D & 58 \\
\hline
\end{tabular}

*Meta-analysis: genes that are associated and have been confirmed by meta-analysis are indicated; the other genes have been associated in a few studies, but the replication must be confirmed in more populations. IBS: irritable bowel syndrome; IBS-D: IBS with diarrhea, IBS-C: IBS with constipation; IBS-M: IBS with mixed symptoms; IBS-U: IBS unsubtyped.

inflammation. Evidence from human mucosal biopsies suggests the existence of neuroplastic remodeling in the intestinal epithelium and afferent nerve terminals that could interfere with the release of neuropeptides from these terminals, resulting in neurogenic inflammation ${ }^{29}$.

The 5-hydroxytryptamine (5-HT), also known as serotonin, is a mediator in the gut-brain interaction. Serotonin plays an important role in intestinal motility and the pathophysiology of IBS, as it is one of the main neurotransmitters involved in peristalsis, intestinal motility, and visceral sensitivity. Ninety-five percent of the serotonin that is formed in the intestine is for endocrine, autocrine, paracrine, and hormonal functions. The inactivation of serotonin occurs by the serotonin reuptake transporter (SERT) to maintain proper levels. Patients with IBS have an altered transcription of SERT. It is elevated in IBS-C, which causes a decrease in the level of serotonin, and it is low in IBS-D, causing an increase in serotonin, which accelerates motility and causes diarrhea and pain ${ }^{30}$.

The motility and sensitivity of the GI tract is modulated in a 5-HT receptor-dependent manner through various receptors through enteric and submucosal neurons. For this reason, different genes involved in the serotonin 
neuronal pathway have been explored as candidate genes for their association with IBS.

A meta-analysis suggested that HTR $3 A$ and HTR3E are associated with a decreased risk of IBS- ${ }^{13}$. However, a review compiled all the genetic information about these receptors and its association with IBS, concluded that there exist ethnic disparities in the association $^{12}$.

The SERT or solute carrier 6A4 (SLC6A4) is a transmembrane transport protein that regulates the reuptake of 5-HT after its interaction with its receptor. This gene contains a 44-base pair deletion or insertion, generating the short or long allele, named 5-HT transporter length polymorphic region (5-HTTL$P R)$. The short variant reduces the expression of SLC6A4, inhibiting the reuptake of serotonin. Several studies had reported association to this gene and has been reviewed elsewhere ${ }^{31,32}$. A recent meta-analysis showed that 5 -HTTLPR is associated with IBS-D in Mongoloid, but not in Caucasian population ${ }^{14}$, remarking the importance of the ethnicity in genetic studies ${ }^{12}$.

Another candidate gene is the catechol-O methyltransferase (COMT), implicated in the degradation of catecholamine, modulating dopaminergic, and adrenergic/noradrenergic neurotransmitters. Its variant rs 4680 provokes a change of amino acids (Val158Met), diminishing the enzyme activity and lowering the pain sensitivity threshold; in addition, rs4680 is associated with IBS ${ }^{21}$. The $\alpha 2$-adrenergic receptors were also evaluated, due to its implication on modifying sensory and motor functions on IBS patients. Discrepancy on the association of this gene with IBS exists among different studies; therefore, more research has to be performed to assess the plausible genetic role of these receptors on IBS 32 .

The $B 3$ subunit of $G$ protein (GN $\beta 3$ ), which modifies the activity of the adrenergic receptors, has been proposed to be associated with IBS. However, a meta-analysis of all the studies analyzing this variant confirmed no evidence of this association ${ }^{14}$ and the allele frequency is different among ethnicities ${ }^{12}$.

Another candidate gene that has been associated with IBS is the neuropeptide $S$ receptor (NPSR1). NPSR1 is a neuropeptide involved in stress, fear, anxiety and it is expressed in the intestinal epithelium and is expressed upon inflammation ${ }^{24}$. NPSR1 induces the expression of CCK, peptide $Y$, and somatostatin $^{33}$. This gene was associated with GI sensory symptoms as gas, pain and urgency, as well as with colonic transit time ${ }^{33}$. However, more populations have to be analyzed to confirm its association with IBS.

\section{Endocrine pathway}

The intensity of symptoms in patients with IBS is related to chronic stress. The key stress-initiated signaling factor is the hormone corticotropin-releasing factor or hormone (CRF or CRH). CRF is a vital hormone in the body's response to stress, activating through the hypothalamic-pituitary-adrenal (HPA) axis in reaction to a variety of physical and psychological stressors. IBS patients have enhanced levels of adrenocorticotropic hormone and cortisol compared to healthy subjects. CRF exerts its biological effects by activating the transmembrane $G$ protein-coupled 
CRFR1 and CRFR2 receptors. CRFR1 is expressed in enteric neurons and in the intestinal mucosa, so stress induces mechanisms that affect GI function, such as delayed gastric emptying or accelerated intestinal and colonic motility ${ }^{34}$. The use of knock-out mice CRFR1 -/ - has revealed the importance of the CRFR1 subtype in IBS like-symptoms, as these mice exhibit decreased visceral sensitivity, as well as decreased anxiety and an impaired stress response ${ }^{35}$.

Therefore, a plausible candidate gene for IBS is $C R F$, which modulates the HPA axis and intestinal mucosa inflammation ${ }^{36}$. Polymorphisms on CRFR1 and CRFR2 were shown to be associated with IBS ${ }^{37}$.

Other candidate genes are the cannabinoid receptors. Anandamide is the main endocannabinoid that binds to the cannabinoid receptors (CB1 and CB2, encoded by the genes CNR1 and CNR2) have also been associated with IBS. CB1 receptors are located in the GI tract, CNS, muscle, fat, and liver; while CB2 are found in immune cells. Anandamide will be synthesized on demand and will inhibit presynaptic neurotransmitters, such as acetylcholine. Then, anandamide is inactivated by the fatty acid amide hydrolase $(F A A H)$, upon inactivity leads to acetylcholine release. Genetic studies were performed, finding that a triplet on CNR1 (AAT)n on 3'flanking region is associated with severity of abdominal pain in IBS and rs806378 with colonic transit in IBS-D ${ }^{38}$. Moreover, the FAAH C385A variant was associated with IBS-D and rapid colon transit ${ }^{38}$. In fact, a recent review summarizes the clinical research about the potential therapeutic benefits of the cannabinoids over the regulation of GI disorders based on gut-brain interactions ${ }^{39}$. However, more genetic studies have to be performed in other populations to assure their implication in IBS.

Cholecystokinin is a neuropeptide that is secreted within the duodenum and the jejunal mucosa. It acts through two receptors CCK1 and CCK2 that are distributed in the CNS and in the GI tract, modulating the colon motility and gastric emptying. CCK1 was associated with IBS-C and IBS-M patients and with a lower GI motility ${ }^{40}$. Further investigation has to confirm its association with IBS.

\section{Immune pathway and microbiota}

In recent years, the role of the gut microbiota in the bidirectional communication of the gut-brain axis has been described, including visceral sensation and nociception ${ }^{41}$.

The microbiota plays an important role in the pathogenesis of IBS, and it is characterized by intestinal dysbiosis. Acute and chronic stress have been shown to affect intestinal secretory IgA levels, which affects intestinal homeostasis, the inflammatory response, and ultimately leads to dysbiosis ${ }^{42}$.

Stress changes the internal environment of the GI tract through immune, neurochemical, and physical mechanisms to make it a less habitable space for certain beneficial bacteria, provoking the growth of pathological species. This can alter the pain signaling mechanisms of the GI tract that contribute to visceral hypersensitivity ${ }^{43}$.

Gut bacteria can modulate the epithelial barrier and the immune response, which ultimately 
increases the expression of tight junction proteins of epithelial cells. This translates into lower intestinal permeability to intraluminal xenobiotics that can cause an inflammatory response ${ }^{41}$.

The influence of the microbiota on the gutbrain axis is suggested through its interaction with the immune system in the gut mucosa. Dysbiosis is related to low-grade intestinal inflammation and triggering the immune system, contributing to GI symptoms and psychological symptoms ${ }^{43}$. Intestinal dysbiosis has been associated with the pathogenesis of $\mathrm{IBS}^{42}$.

A systematic review and meta-analysis of case-control studies compared the gut microbiota of people with IBS and healthy controls. In people with IBS, there was a decrease in the number of Lactobacillus and Bifidobacterium; on the other hand, they had elevation of Escherichia coli and Enterobacter. No differences were found in the number of Bacteroides and Enterococcus ${ }^{44}$. However, a specific dysbiotic signature has not yet been established through the different studies.

Cytokines regulate immune and inflammatory responses and their production is genetically regulated. Therefore, the cytokines are candidate genes for IBS. Some of the cytokines that have been studied are: tumor necrosis factor-alpha (TNF- $\alpha)$, transforming growth factor beta 1, interleukin (IL)-6 (IL-6), IL-8, IL10, IL-32 receptor (IL-32R) and TNFSF15.

In postinfectious IBS, it is more likely that there is subtle intestinal inflammation with infiltration of mast cells in the colon and small intestine ${ }^{45}$. A study that measured the pro-inflammatory cytokine profile in patients with
IBS vs. healthy controls, demonstrated that IBS patients have higher serum levels of IL-1 $\beta$, IL-6, IL-8, TNF-b and IL-10, although it is not clear a causal relationship between the levels of these cytokines and the symptoms of IBS ${ }^{46}$.

Interestingly, in a Mexican population, Blastocystis infection (a commensal parasite) was reported to be associated with IBS; however, IL-6 and TNF- $\alpha$ were not associated with IBS ${ }^{47}$. Moreover, in another study IL-10 and TNF- $\alpha$ were not associated with IBS, but IBS-D subjects presented lower producer IL-10 genotype, suggesting predisposition due to a lower anti-inflammatory ${ }^{48}$. Another cytokine, IL- 8 has been reported to be associated in Mexican population. The IL8 +396 G allele was overrepresented in Mexicans with IBS compared to controls and it was associated with an increased risk to develop IBS $^{49}$. In addition, $I L-8$ and $I L-10$ variants increase the development of IBS in the presence of Blastocystis ${ }^{50}$. A recent study analyzed the gene variants and the gut microbiota in a Mestizo IBS cohort, finding 76 polymorphisms associated with IBS and the enrichment of Bacteroides, Alteromonas, Neisseria, Streptococcus, and Microbacterium in IBS subjects ${ }^{51}$. However, these associations have to be confirmed in other populations.

Several genetic studies have tried to demonstrate its association with IBS. However, there is discrepancy about its association and among ethnicities. Therefore, several meta-analysis summarized all the previous data reported $^{25,52}$. The latest meta-analysis, from 2019 , reported that the pro-inflammatory mediator IL6 rs1800795 increased the risk for IBS in Caucasian population and IL23R rs11465804 
was associated with an increased risk for IBS-C. Moreover, the inhibitor of pro-inflammatory mediators and TNF synthesis, IL10 rs1800896 was associated with a decreased risk of IBS and IL10 rs1800871 was not associated. Moreover, no evidence of association was found for TNF $\alpha$ rs180062914.

TNFSF15 encodes for TL1A, which is a member of the TNF superfamily. It binds to death receptor 3, triggering secretion of inflammatory cytokines like IL-17 via T-helper 17 cell proliferation and differentiation ${ }^{53}$. It has been previously published that increased TNFSF15 levels are present in IBS and in Crohn's disease patients ${ }^{54,55}$. Several meta-analysis pointed out the association of TNFSF15 rs4263839 with IBS showing, particularly with IBS-C ${ }^{14,25}$, and TNFSF15 rs6478108 T allele increased IBS risk as well, but no association was found in subgroup analysis ${ }^{14}$.

As a summary of this section, the most recent meta-analysis showed that SLC6A4 5-HTTLPR, TNFSF15 rs4263839 and rs6478108 conferred risk to develop IBS, and IL6 rs1800795 increased the risk for Caucasians IBS patients; IL23R rs11465804 increased the risk for IBS-C patients; whether, COMT rs4680 and IL10 rs1800896 were protective for IBS; and GN $\beta 3$ rs5443, TNF $\alpha$ rs1800629, IL10 rs1800871 did not show association with IBS (Table 1) ${ }^{14}$.

Moreover, another recent review analyzed IBS-related variants and their association depending upon the ethnicity. In this paper, they emphasized the importance of considering the ethnicities, to better understand the genes associated with IBS and their function, to prevent and ameliorate the treatment for $\mathrm{IBS}^{12}$.

\section{Other mechanisms for candidate genes}

Besides the three typical pathways involved in IBS (neural, endocrine, and immune), there are other mechanisms, such as sodium channels or dissacharidases that could play a role in gut motility that could lead to IBS.

The voltage-gated sodium channel NaV1.5 encoded by the gen SCN5A is expressed in the intestinal smooth muscle cells and interstitial cells of Cajal that mediate the GI contractions ${ }^{56}$. SCN5A gene sequencing in a case-control cohort revealed that $2 \%$ of all IBS cases presented functionally deleterious mutations ${ }^{57}$. Remarkably, SCN5A loss of function mutations provoked a reduction of the $\mathrm{Na}+$ current impairing its function and leading to a channelopathy ${ }^{11}$, making it a good biomarker for IBS.

For the next candidate gene, two important concepts have to be introduced: nutrigenetics and nutrigenomics. Nutrigenetics is the science that studies how the genotype of an individual determines the optimal dietary requirements. On the other hand, nutrigenomics studies how the diet influences the DNA structure, hence the gene expression.

When we talk about IBS nutrigenetics, the sucrase-isomaltase gene is a clear example of it. Sucrase-isomaltase is a disaccharidase enzyme present in the small intestine that degrades starch or digested sugars. Sucrase-isomaltase deficiency or intolerance is characterized by carbohydrate malabsorption, having as a consequence diarrhea, bloating, abdominal pain, similar to IBS-D. 
Therefore, this sucrase-isomaltase is a good candidate gene for IBS.

The sucrase-isomaltase variant Val15Phe was associated with increased risk of IBS, and it correlated with stool frequency and Parabacteroide faecal microbiota abundance. Interestingly, this variant reduced $35 \%$ the enzyme activity, predisposing the individual to IBS ${ }^{58}$.

\section{GWAS: variants without hypothesis, "from genomics to physiology"}

As mentioned above, the candidate gene approach consists on knowing the gene's function, previously to be genetically analyzed in a case-control cohort. However, for the GWAS approach, the polymorphisms are randomly chosen, covering the entire genome. Therefore, the GWAS is a hypothesis-free approach, because the polymorphisms are not selected in a specific gene, nor the function is known.

The GWAS approach provoked a revolution in the genetic area. When using a candidate approach, we could only analyze one or few genes at the same time and prove its association to a disease, performing genetics. However, the GWAS technique consists on analyzing millions of gene variants (polymorphisms) at the same time, on a case-control cohort. Then, allelic frequency comparison between the individuals presenting the disease vs. the controls is analyzed, obtaining a list of gene variants associated with IBS, and becoming genomics instead of genetics (Fig. 1E).

It is important to clarify that the polymorphisms reported to be associated with a disease by a GWAS approach, could be many kilobases or megabases far from the gene and they can be in intergenic regions, promoters, introns or exons. These variants are not chosen by the location of the gene or their function. So when reading a GWAS report, the name of the gene reported to be associated with a disease is the closest gene to the variant. That variant not necessarily regulates the gene next to it nor has a known function that could explain the IBS phenotype. Therefore, we then go "from genomics to physiology" to understand the function of that gene and variant.

Several IBS GWAS have been reported until now $^{10,59,60}$. The first exploratory GWAS was performed in a general population of 11,326 Swedish twins. From this first pilot study, the variants that were associated were replicated in 6 different case-control cohorts from the United States, Greece, Italy, Germany, Belgium, and Sweden and performed a meta-analysis. The locus on chromosome 7p22.1 was associated to higher risk of IBS and it includes two genes: KDELR2 (KDEL endoplasmic reticulum protein retention receptor 2) and GRID2IP (glutamate receptor, ionotropic, delta 2 [Grid2] interacting protein). Moreover, genetic variants on that region modulate KDLER2 mRNA expression, having a trend for higher rectal mucosal KDLER2 mRNA expression in IBS cases versus controls. In addition, this study reported a nominal significance for association with IBS for candidate genes, such as TNFSF15, SCN5A, COMT, NPSR1, and SLC6A4, as mentioned above, Table $2^{10}$.

It is unknown how these variants in this locus could regulate the genes that are close to them (KDELR2 or GRID2IP) or even if those variants can regulate genes that are far 
apart and could be the cause of the disease. However, it is proposed that KDLER2 belongs to a receptor family, which cycles between the Golgi apparatus and the endoplasmic reticulum controlling endoplasmic reticulum quality control and stress response. The researchers suggested that KDELR2 could mediate effects of bacterial toxins in the gut, hence influencing IBS. On the other hand, GRID2IP encodes for a delphilin that is expressed in fiber-Purkinje cell synapses in the brain, where it binds to the monocarboxylate transporter 2, which is present in the enteric nervous system, hence leading to $\mathrm{IBS}^{10}$.

Later, a GWAS meta-analysis of five population-based cohorts was performed to study the IBS association in 18,659 individuals from Finland, Germany, the Netherlands, Sweden, and the United Kingdom. The results showed 7 genomic regions, harboring 64 gene candidates associated with IBS. Functional annotation through gene set enrichment analysis was obtained with functional class scoring against gene ontology resulting in enrichment in molecular signatures of: channel regulatory activity, ion channel activity, and liver genes- metabolism and xenobiotics. On the biological process, there was enrichment on regulation of sodium ion transmembrane transporter activity and the molecular function was a sodium channel regulator activity. In addition, association of SCN5A, SI, NPSR1 genes with IBS was confirmed, as well as KDELR2/ GRID2IP obtained in the previous GWAS ${ }^{60}$.

Preliminary data from a study that is still in review, analyzed variants association with the stool frequency to study the genetics of gut motility. They identified 13-loci involved in sensory perception and neurotransmitter/ neuropeptide signaling, enriched expression in enteric motor neurons associated with peristalsis, GI motility and dysmotility syndromes. Surprisingly, the BDNF locus (rs12273363) was associated with IBS, lying in the promoter region of $B D N F$, repressing its activity. BDNF is recognized to have gut functions as sensation, neuroprotection, neuroplasticity, motility and epithelial barrier ${ }^{61}$. Other genes reported to be associated to stool frequency were acetylcholinesterase $(A C H E)$, fatty acid hydroxylase (FAXDC2), and protein kinase expressed in colonic M cells and BEST4+ enterocytes (CDK18) ${ }^{61}$. However, all this data has to be peer-reviewed and published, as well as confirmed to have an impact on IBS.

More evidence is accumulating about the role of genes involved in gut motility and neurotransmission of enteric neurons implicated on IBS. In fact, the enteric nervous system coordinates GI homeostasis and digestive processes, establishing a gut-brain axis ${ }^{62}$.

Therefore, after the genomic era, where several variants were reported to be associated with a disease, the challenge now is to discover the function of those gene variants and its implication in the disease. This may lead to changing the mindset from genomics to physiology, understanding the implication of the genes in the etiology of IBS.

\section{CONCLUSION}

Genetic and genomic studies have been crucial to identify several genes associated with IBS. With a candidate gene or a hypothesis free approach (GWAS) several variants have been reported to be associated with IBS. 
TABLE 2. Genes associated with IBS discovered by GWAS approach

\begin{tabular}{|c|c|c|c|c|c|}
\hline Closest gene & Gene function & Variants & Associated effect & Type of IBS & Reference \\
\hline $\begin{array}{l}\text { KDELR2 (KDEL } \\
\text { endoplasmic } \\
\text { reticulum protein } \\
\text { retention receptor 2) }\end{array}$ & $\begin{array}{l}\text { Vesicle trafficking and transport } \\
\text { into the endoplasmic reticulum }\end{array}$ & $\begin{array}{l}\text { rs12702514 } \\
\mathrm{T} / \mathrm{C} \\
\text { rs4574760 C/T }\end{array}$ & $\begin{array}{l}\text { Might mediate effects } \\
\text { of bacterial toxins }\end{array}$ & IBS & 10,60 \\
\hline $\begin{array}{l}\text { GRID2IP (Glutamate } \\
\text { receptor, ionotropic, } \\
\text { delta } 2 \text { [Grid2] } \\
\text { interacting protein) }\end{array}$ & $\begin{array}{l}\text { Encodes for a delphilin that is } \\
\text { expressed in fiber-Purkinje cell } \\
\text { synapses in the brain, where it } \\
\text { binds to the monocarboxylate } \\
\text { transporter } 2\end{array}$ & $\begin{array}{l}\text { rs13222291 } \\
A / G \\
\text { rs4574760 C/T }\end{array}$ & $\begin{array}{l}\text { Might affect } \\
\text { host-microbiota } \\
\text { interactions in relation } \\
\text { to gut motility }\end{array}$ & IBS & 10,60 \\
\hline $\begin{array}{l}\text { TNFSF15 (TL1A) } \\
\text { (TNF Superfamily } \\
\text { Member 15) }\end{array}$ & $\begin{array}{l}\text { Encodes for TL1A, which is a } \\
\text { member of the tumor necrosis } \\
\text { factor superfamily. It binds to } \\
\text { death receptor } 3 \text { (DR3), } \\
\text { triggering secretion of } \\
\text { interleukin } 17\end{array}$ & rs7867918 G/T & $\begin{array}{l}\text { Probably inflammation } \\
\text { of the bowel mucosa }\end{array}$ & $\begin{array}{l}\text { IBS, IBS-C, IBS-D, } \\
\text { IBS-A }\end{array}$ & 10 \\
\hline $\begin{array}{l}\text { SCN5A (Sodium } \\
\text { Voltage-Gated } \\
\text { Channel Alpha } \\
\text { Subunit 5) }\end{array}$ & $\begin{array}{l}\text { Expressed in the intestinal } \\
\text { smooth muscle cells and } \\
\text { interstitial cells of Cajal that } \\
\text { mediate the Gl contractions }\end{array}$ & $\begin{array}{l}\text { rs7432532 C/A } \\
\text { rs7430407 C/T }\end{array}$ & $\begin{array}{l}\text { Reduction of the } \mathrm{Na}+ \\
\text { current impairing its } \\
\text { function and leading } \\
\text { to a channelopathy }\end{array}$ & IBS & 10,60 \\
\hline $\begin{array}{l}\text { COMT (Catechol } \\
\text { 0-Methyltransferase) }\end{array}$ & Degradation of catecholamines & rs9332348 C/A & $\begin{array}{l}\text { Decreases its enzyme } \\
\text { activity and pain } \\
\text { threshold }\end{array}$ & IBS & 10 \\
\hline $\begin{array}{l}\text { NPSR1 (Neuropep- } \\
\text { tide S receptor) }\end{array}$ & $\begin{array}{l}\text { Involved in stress, fear and } \\
\text { anxiety. Increases the } \\
\text { expression of CCK, somatostatin } \\
\text { and peptide Y }\end{array}$ & $\begin{array}{l}\text { rs324389 C/A } \\
\text { rs324381 G/T }\end{array}$ & $\begin{array}{l}\text { Increased intestinal } \\
\text { motility, gas, } \\
\text { abdominal pain and } \\
\text { urgency to defecate }\end{array}$ & $\begin{array}{l}\text { Colonic transit, } \\
\text { sensory ratings } \\
\text { IBS }\end{array}$ & 10,60 \\
\hline $\begin{array}{l}\text { SLC6A4 (Solute } \\
\text { Carrier Family } 6 \\
\text { Member 4) }\end{array}$ & $\begin{array}{l}\text { Encodes for SERT (Transporter } \\
\text { in serotonin reuptake) }\end{array}$ & rs8073965 G/A & $\begin{array}{l}\text { Decreases the activity } \\
\text { of SERT and } \\
\text { accelerates intestinal } \\
\text { peristalsis }\end{array}$ & $\begin{array}{l}\text { IBS, IBS-C, IBS-D, } \\
\text { colonic transit }\end{array}$ & 10 \\
\hline $\begin{array}{l}\text { SI (Sucrase-isomal- } \\
\text { tase) }\end{array}$ & $\begin{array}{l}\text { Disaccharidase enzyme present } \\
\text { in the small intestine, degra- } \\
\text { dates starch or digested sugars }\end{array}$ & $\begin{array}{l}\text { rs } 75982521 \\
\text { C/A }\end{array}$ & $\begin{array}{l}\text { Carbohydrates } \\
\text { malabsortion }\end{array}$ & $\begin{array}{l}\text { Diarrhea, bloating, } \\
\text { abdominal pain, } \\
\text { similar to IBS-D }\end{array}$ & 60 \\
\hline $\begin{array}{l}\text { BDNF (Brain-Derived } \\
\text { Neurotrophic Factor ) }\end{array}$ & $\begin{array}{l}\text { Promotes the survival and } \\
\text { differentiation of selected } \\
\text { neuronal populations of the } \\
\text { peripheral and central nervous } \\
\text { systems }\end{array}$ & $\begin{array}{l}\text { rs12273363 } \\
\text { T/A }\end{array}$ & $\begin{array}{l}\text { Gut functions as } \\
\text { sensation, neuropro- } \\
\text { tection, neuroplastici- } \\
\text { ty, motility, and } \\
\text { epithelial barrier }\end{array}$ & $\begin{array}{l}\text { Repressing its activity } \\
\text { Stool frequency }\end{array}$ & $\begin{array}{c}\text { under review } \\
61{ }^{*} \text { eOTLs }\end{array}$ \\
\hline $\begin{array}{l}\text { ACHE (acetylcholin- } \\
\text { esterase) }\end{array}$ & $\begin{array}{l}\text { Hydrolyzes acetylcholine at } \\
\text { neuromuscular junctions; } \\
\text { expressed in enteric and motor } \\
\text { neurons }\end{array}$ & rs4556017 C/T & Gut motility & Stool frequency & $\begin{array}{l}\text { under review } \\
\qquad 61 \text { * } \mathrm{eTL}\end{array}$ \\
\hline $\begin{array}{l}\text { FAXDC2 (fatty acid } \\
\text { hydroxylase) }\end{array}$ & $\begin{array}{l}\text { Hydrolyzes fatty acid; expressed } \\
\text { in enteric and motor neurons }\end{array}$ & $\begin{array}{l}\text { rs } 13162291 \\
\text { G/A }\end{array}$ & Gut motility & Stool frequency & $\begin{array}{l}\text { under review } \\
61{ }^{*} \mathrm{e} \mathrm{TTL}\end{array}$ \\
\hline $\begin{array}{l}\text { CDK18 (Cyclin } \\
\text { Dependent } \\
\text { Kinase 18) }\end{array}$ & $\begin{array}{l}\text { Protein kinase expressed in } \\
\text { colonic M cells and BEST4 + } \\
\text { enterocytes }\end{array}$ & $\begin{array}{l}\text { rs11240503 } \\
\text { G/A }\end{array}$ & $\begin{array}{l}\text { Senses electrolyte and } \\
\mathrm{pH} \text {; colonic osmolarity, } \\
\text { and transit }\end{array}$ & Stool frequency & $\begin{array}{l}\text { under review } \\
61 * \mathrm{e} Q T L\end{array}$ \\
\hline
\end{tabular}

${ }^{*}$ eQTL: expression quantitative trait loci. 
However, the challenge now is to understand the implication of those variants in conferring susceptibility to develop the disease and their relation to the underlying pathophysiological mechanism of this GBID.

\section{FUNDING}

This project was not funded by any private or public institution.

\section{CONFLICTS OF INTEREST}

The authors have no conflict of interest to declare.

\section{ETHICAL DISCLOSURES}

Protection of human and animal subjects. The authors declare that no experiments were performed on humans or animals for this study.

Confidentiality of data. The authors declare that no patient data appear in this article.

\section{Right to privacy and informed consent. The authors declare that no patient data appear in this article.}

\section{REFERENCES}

1. Lacy BE, Mearin F, Chang L, Chey WD, Lembo AJ, Simren M, et al. Bowel disorders. Gastroenterology. 2016;150:1393-407.e5.

2. Schmulson MJ, Drossman DA. What is new in Rome IV. J Neurogastroenterol Motil. 2017;23:151-63.

3. Simren M, Palsson OS, Whitehead WE. Update on Rome IV criteria for colorectal disorders: implications for clinical practice. Curr Gastroenterol Rep. 2017;19:5378729.

4. Ford AC, Lacy BE, Talley NJ. Irritable bowel syndrome. N Engl J Med. 2017;376:2566-78.
5. Sperber AD, Dumitrascu D, Fukudo S, Gerson C, Ghoshal UC, Gwee KA, et al. The global prevalence of IBS in adults remains elusive due to the heterogeneity of studies: a Rome Foundation working team literature review. Gut. 2017;66:1075-82.

6. Sperber AD, Bangdiwala SI, Drossman DA, Ghoshal UC, Simren M, Tack J, et al. Worldwide prevalence and burden of functional gastrointestinal disorders, results of Rome foundation global study. Gastroenterology. 2021;160:99-114.e3.

7. Hu Z, Li M, Yao L, Wang Y, Wang E, Yuan J, et al. The level and prevalence of depression and anxiety among patients with different subtypes of irritable bowel syndrome: a network meta-analysis. BMC Gastroenterol. 2021;21:7791666.

8. Canavan C, West J, Card T. Review article: the economic impact of the irritable bowel syndrome. Alimentary Pharmacology and Therapeutics. Vol. 40. United States: Blackwell Publishing Ltd.; 2014. p. 1023-34.

9. Low EX, Al Mandhari MN, Herndon CC, Loo EX, Tham EH, Siah KT. Parental, perinatal, and childhood risk factors for development of irritable bowel syndrome: a systematic review. J Neurogastroenterol Motil. 2020;26:437-46.

10. Ek WE, Reznichenko A, Ripke S, Niesler B, Zucchelli M, Rivera NV, et al. Exploring the genetics of irritable bowel syndrome: a GWA study in the general population and replication in multinational case-control cohorts. Gut. 2015;64:1774-82.

11. Saito YA, Strege PR, Tester DJ, Locke GR, Talley NJ, Bernard CE, et al. Sodium channel mutation in irritable bowel syndrome: evidence for an ion channelopathy. Am J Physiol. 2009;296:G211-8.

12. Xiao QY, Fang XC, Li XQ, Fei GJ. Ethnic differences in genetic polymorphism associated with irritable bowel syndrome. World J Gastroenterol 2020;26:2049-63.

13. Guan T, Li T, Cai W, Huang D, Ouyang P, Wang Y, et al. HTR3A and HTR3E gene polymorphisms and diarrhea predominant irritable bowel syndrome risk: evidence from a meta-analysis. Oncotarget. 2017;8:100459-68.

14. Zhu S, Wang B, Jia Q, Duan L. Candidate single nucleotide polymorphisms of irritable bowel syndrome: a systemic review and meta-analysis. BMC Gastroenterol. 2019;19:165.

15. Levy RL, Jones KR, Whitehead WE, Feld SI, Talley NJ, Corey LA. Irritable bowel syndrome in twins: heredity and social learning both contribute to etiology. Gastroenterology. 2001;121:799-804.

16. Bengtson MB, Rønning T, Vatn MH, Harris JR. Irritable bowel syndrome in twins: genes and environment. Gut. 2006;55:1754-9.

17. Waehrens R, Zöller B, Sundquist J, Sundquist K, Pirouzifard MN. A Swedish national adoption study of risk of irritable bowel syndrome (IBS). BMJ Open Gastroenterol. 2017;4:e000156.

18. Zucchelli M, Camilleri M, Andreasson AN, Bresso F, Dlugosz A, Halfvarson J, et al. Association of TNFSF15 polymorphism with irritable bowel syndrome. Gut. 2011;60:1671-7.

19. Kumar S, Ranjan P, Mittal B, Ghoshal UC. Serotonin transporter gene (SLC6A4) polymorphism in patients with irritable bowel syndrome and healthy controls. J Gastrointest Liver Dis. 2012;21:31-8.

20. Kapeller J, Houghton LA, Mönnikes H, Walstab J, Möller D, Bönisch H, et al. First evidence for an association of a functional variant in the microRNA-510 target site of the serotonin receptor-type 3E gene with diarrhea predominant irritable bowel syndrome. Hum Mol Genet. 2008;17:2967-77.

21. Karling P, Danielsson A, Wikgren M, Soderstrom I, Del-favero J, Adolfsson R, et al. The relationship between the Val158Met catechol-o- methyltransferase (COMT) polymorphism and irritable bowel syndrome. PLoS One. 2011;6:1-5.

22. Vaiopoulou A, Karamanolis G, Psaltopoulou T, Karatzias G, Gazouli M. Molecular basis of the irritable bowel syndrome. World J Gastroenterol. 2014;20:376-83

23. Makker J. Genetic epidemiology of irritable bowel syndrome. World J Gastroenterol. 2015;21:11353.

24. Henström M, D’Amato M. Genetics of irritable bowel syndrome. Mol Cell Pediatr. 2016;3:3-7. 
25. Czogalla B, Schmitteckert S, Houghton LA, Sayuk GS, Camilleri M, Olivo-Diaz A, et al. A meta-analysis of immunogenetic case-control association studies in irritable bowel syndrome. Neurogastroenterol Motil. 2015;27:717-27.

26. Stasi C, Rosselli M, Bellini M, Laffi G, Milani S. Altered neuro-endocrine-immune pathways in the irritable bowel syndrome: the top-down and the bottom-up model. J Gastroenterol. 2012;47:1177-85.

27. Buckley MM, O'mahony SM, O'malley D. Convergence of neuro-endocrine-immune pathways in the pathophysiology of irritable bowel syndrome WJG $20^{\text {th }}$ anniversary special issues (4): irritable bowel syndrome TOPIC HIGHLIGHT. World J Gastroenterol. 2014;20:8846-58.

28. Lomax AE, Sharkey KA, Furness JB. The participation of the sympathetic innervation of the gastrointestinal tract in disease states. Neurogastroenterol Motil. 2010;22:7-18.

29. Spiller R, Garsed K. Postinfectious irritable bowel syndrome. Gastroenterology. 2009;136:1979-88.

30. Jin DC, Cao HL, Xu MQ, Wang SN, Wang YM, Yan F, et al. Regulation of the serotonin transporter in the pathogenesis of irritable bowel syndrome. World J Gastroenterol. 2016;22:8137-48.

31. Camilleri M. Genetics and irritable bowel syndrome: from genomics to intermediate phenotype and pharmacogenetics. Dig Dis Sci. 2009;54:2318-24.

32. Camilleri M, Katzka DA. Irritable bowel syndrome : methods, mechanisms, and pathophysiology. Genetic epidemiology and pharmacogenetics in irritable bowel syndrome. Am J Physiol. 2012;302:G1075-84.

33. Camilleri M, Carlson P, Zinsmeister AR, McKinzie S, Busciglio I, Burton D, et al. Neuropeptide $S$ receptor induces neuropeptide expression and associates with intermediate phenotypes of functional gastrointestinal disorders. Gastroenterology. 2010;138:98-107.

34. Chatzaki E, Crowe PD, Wang L, Million M, Taché Y, Grigoriadis DE. CRF receptor type 1 and 2 expression and anatomical distribution in the rat colon. J Neurochem. 2004;90:309-16.

35. Trimble N, Johnson AC, Foster A, Greenwood-Van Meerveld B. Corticotropin-releasing factor receptor 1-deficient mice show decreased anxiety and colonic sensitivity. Neurogastroenterol Motil. 2007;19:754-60.

36. Fukudo S. Stress and visceral pain: focusing on irritable bowel syndrome. Pain. 2013;154 Suppl 1:S63-70.

37. Sato N, Suzuki N, Sasaki A, Aizawa E, Obayashi T, Kanazawa M, et al. Corticotropin-releasing hormone receptor 1 gene variants in irritable bowel syndrome. PLoS One. 2012;7:1-8.

38. Camilleri M, Carlson P, Mckinzie S, Grudell A, Busciglio I, Burton D, et al. Genetic variation in endocannabinoid metabolism, gastrointestinal motility, and sensation. Am J Physiol Gastrointest Liver Physiol. 2008;294:13-9.

39. Arboleda MF, Prosk E, Watier A, Schmulson-Wasserman M. Cannabinoids in disorders of gut-brain interaction and gastrointestinal motility. NeuroGastroLATAM Rev. 2021;4:171-86.

40. Park S, Rew J, Lee S, Ki H, Lee K, Cheo J, et al. Association of CCK(1) syndrome, receptor gene polymorphisms and irritable bowel. J Neurogastroenterol Motil. 2010;16:71-6.

41. Polster A, Öhman L, Tap J, Derrien M, Le Nevé B, Sundin J, et al. A novel stepwise integrative analysis pipeline reveals distinct microbiota-host interactions and link to symptoms in irritable bowel syndrome. Sci Rep. 2021;11:7943560.

42. Campos-Rodríguez R, Godínez-Victoria M, Abarca-Rojano E, Pacheco-Yépez J, Reyna-Garfias H, Barbosa-Cabrera RE, et al. Stress modulates intestinal secretory immunoglobulin A. Front Integ Neurosci. 2013;7:3845795.

43. Moloney RD, Johnson AC, O'Mahony SM, Dinan TG, Greenwood-Van Meerveld B, Cryan JF. Stress and the microbiota-gut-brain axis in visceral parelevance to irritable bowel syndrome. CNS Neurosci Ther. 2016;22:102-17.

44. Wang L, Alammar N, Singh R, Nanavati J, Song Y, Chaudhary R, et al. Gut microbial dysbiosis in the irritable bowel syndrome: a systematic review and meta-analysis of case-control studies. J Acad Nutr Diet. 2020;120:565-86.

45. Keely S, Walker MM, Marks E, Talley NJ. Immune dysregulation in the functional gastrointestinal disorders. Eur J Clin Investig. 2015;45:1350-9.
46. Bennet SM, Palsson O, Whitehead WE, Barrow DA, Törnblom H, Öhman L, et al. Systemic cytokines are elevated in a subset of patients with irritable bowel syndrome but largely unrelated to symptom characteristics. Neurogastroenterol Motil. 2018;30:30.

47. Jimenez-Gonzalez DE, Martinez-Flores WA, Reyes-Gordillo J, Ramirez-Miranda ME, Sara Arroyo-Escalante, Romero-Valdovinos M, et al. Blastocystis infection is associated with irritable bowel syndrome in a Mexican patient population. Parasitol Res. 2012;110:1269-75.

48. Schmulson M, Pulido-London D, Rodríguez Ó, Morales-Rochlin N, Martínez-García R, Gutiérrez-Ruiz MC, et al. IL-10 and TNF-and\#945; polymorphisms in subjects with irritable bowel syndrome in Mexico. Rev Esp Enferm Dig. 2013;105:392-9.

49. Romero-Valdovinos M, Gudiño-Ramírez A, Reyes-Gordillo J, MartínezFlores WA, Ramírez-Miranda ME, Maravilla P, et al. Interleukin-8 and-10 gene polymorphisms in irritable bowel syndrome. Mol Biol Rep. 2012;39:8837-43.

50. Olivo-Diaz A, Romero-Valdovinos M, Gudiño-Ramirez A, Reyes-Gordillo J, Jimenez-Gonzalez DE, Ramirez-Miranda ME, et al. Findings related to IL-8 and IL-10 gene polymorphisms in a Mexican patient population with irritable bowel syndrome infected with Blastocystis. Parasitol Res. 2012;111:487-91.

51. Arredondo-Hernández R, Schmulson M, Orduña P, López-Leal G, Zarate AM, Alanis-Funes G, et al. Mucosal microbiome profiles polygenic irritable bowel syndrome in mestizo individuals. Front Cell Infect Microbiol. 2020;10:72.

52. Bashashati M, Rezaei N, Bashashati H, Shafieyoun A, Daryani NE, Sharkey KA, et al. Cytokine gene polymorphisms are associated with irritable bowel syndrome: a systematic review and meta-analysis. Neurogastroenterol Motil. 2012;24:1102-e566.

53. Pappu BP, Borodovsky A, Zheng TS, Yang X, Wu P, Dong X, et al. TL1ADR3 interaction regulates Th17 cell function and Th17-mediated autoimmune disease. J Exp Med. 2008;205:1049-62.

54. Kakuta Y, Ueki N, Kinouchi Y, Negoro K, Endo K, Nomura E, et al. TNFSF15 transcripts from risk haplotype for Crohn's disease are overexpressed in stimulated T cells. Hum Mol Genet. 2009;18:1089-98.

55. Swan C, Duroudier NP, Campbell E, Zaitoun A, Hastings M, Dukes GE, et al. Identifying and testing candidate genetic polymorphisms in the irritable bowel syndrome (IBS): association with TNFSF15 and TNF $\alpha$. Gut. 2013;62:985-94.

56. Strege PR, Ou Y, Sha L, Rich A, Gibbons SJ, Szurszewski JH, et al. Sodium current in human intestinal interstitial cells of Cajal. Am J Physiol Gastrointest Liver Physiol. 2003;285:G1111-21.

57. Beyder A, Mazzone A, Strege PR, Tester DJ, Saito YA, Bernard CE, et al. Lossof-function of the voltage-gated sodium channel NaV1.5 (Channelopathies) in patients with irritable bowel syndrome. Gastroenterology. 2014;146:1659-68.

58. Henström M, Diekmann L, Bonfiglio F, Hadizadeh F, Kuech EM, Von Köckritz-Blickwede $\mathrm{M}$, et al. Functional variants in the sucrase-isomaltase gene associate with increased risk of irritable bowel syndrome. Gut. 2018;67:263-270.

59. Holliday EG, Attia J, Hancock S, Koloski N, McEvoy M, Peel R, et al. Genome-wide association study identifies two novel genomic regions in irritable bowel syndrome. Am J Gastroenterol. 2014;109:770-2.

60. Bonfiglio F, Henström M, Nag A, Hadizadeh F, Zheng T, Cenit MC, et al. A GWAS meta-analysis from 5 population-based cohorts implicates ion channel genes in the pathogenesis of irritable bowel syndrome. Neurogastroenterol Motil. 2018;30:1-11.

61. Bonfiglio F, Liu X, Smillie C, Pandit A, Kurilshikov A, Bacigalupe R, et al. GWAS of stool frequency reveals genes, pathways, and cell types relevant to human gastrointestinal motility and irritable bowel syndrome. MedRxiv. 2020;20132555.

62. Holland AM, Bon-Frauches AC, Keszthelyi D, Melotte V, Boesmans W. The enteric nervous system in gastrointestinal disease etiology. Cell Mol Life Sci. 2021;78(10):4713-33.

63. Komuro H, Sato N, Sasaki A, Suzuki N, Kano M, Tanaka Y, et al. Corticotropin-releasing hormone receptor 2 gene variants in irritable bowel syndrome. PLoS One. 2016;11:e0147817. 